\begin{tabular}{|c|c|c|}
\hline $\begin{array}{l}\text { EXCELLENT } \\
\text { PURI ISHERS }\end{array}$ & $\begin{array}{c}\text { International Journal of Current Research } \\
\text { and Academic Review } \\
\text { ISSN: 2347-3215 (Online) }\end{array}$ & \\
\hline
\end{tabular}

doi: https://doi.org/10.20546/ijcrar.2017.511.004

\title{
Evaluation of Impact Cadmium on Geo-Environment of Dibbis City in Kirkuk Government / Northern Iraq
}

\author{
Hassan A. A. Aljumaily ${ }^{1}$ and Ahmed H. M. Al-hamdany ${ }^{2 *}$ \\ ${ }^{I}$ Department of Applied Geology, College of Science, University of Kirkuk, Kirkuk, Iraq \\ ${ }^{2}$ Master student/Department of Applied Geology, College of Science, University of Kirkuk, Kirkuk, Iraq \\ *Corresponding author
}

\section{Abstract}

The present study is to evaluate and investigate the distribution of cadmium element (cd) in soil of Dibbis City northern Iraq, by using Index (Igeo), (CF) and (EF). The concentration of cadmium were determined by using (ICP-MS) technique in Acme Lame of (Canada). Collected (8) Samples in July/2016, In each site taken two samples for two depth $(0-20 \mathrm{~cm})(20-40 \mathrm{~cm})$. The results showing that the highest concentration of cd found in Hai Al-Taakhy with value $(0.245 \mathrm{ppm})$ because its station is burial health of waste of city, then Hai Al-Askary (S3) with value $(0.225 \mathrm{ppm})$ it was in the past agriculture are riched by phosphate fertilizer in addition to military district. The calculated Igeo values of $\mathrm{Cd}$ is unpolluted to moderately polluted in all sites of Dibbis soil, The Contamination Factor of Cd investigated in soil of present study Moderate contamination for all station and Enrichment Factor results of the Cd investigated in this present study of soil is indicates Moderate enrichment.
\end{abstract}

\section{Article Info}

Accepted: 28 October 2017

Available Online: 20 November 2017

\section{Keywords}

Cadmium,

Dibs,

Contamination Factor,

Iraq

\section{Introduction}

Cadmium is toxic elements with symbol $\mathrm{Cd}$ and atomic number 48 occurring in the environment by two ways, naturally and as a pollutant from industrial and agricultural sources, that can cause health hazards when exposed populations were emphasized later (Kaji, 2012). Cadmium occurs at +2 oxidation state, and easily forms complex cataions and anions, especially with $\mathrm{Cl}, \mathrm{S}$, and $\mathrm{OH}$, It exhibits chalcophilic properties and behaves very similar to $\mathrm{Zn}$, but has a stronger at finity for $\mathrm{S}$, and is more mobile in acidic environments (Kabata-Pendias and Szteke, 2015). Cd ranks as the 65 the most abundant elements in the Earth's crust (Shahid et al., 2016), While cd can be found together with the $\mathrm{Zn}$ ore sphalerite, greewockite (cds) is the only known Cd-based ore (Rao et al., 2011). Human exposure to cadmium in excessive concentrations has the potential to cause, bone lesions, lung insufficiency, cancer, erotogenic effects, renal (disturbances, anemia, hypertension and weight loss (Alina Kabata-Pendias, 2011), Because of it's potential to cause such adverse effects, cd is classed as potential human carcinogen (group2B) by the Us Environmental Protection Agency (EPA), human carcinogen (group1) by the International Agency for Research on cancer of the world Health organization (WHO) (Shahid et al., 2016), and ranked No.7 among the top 20 priority hazardous substances by the Agency for Toxic substances and Disease Registry (ATSDR, 2012)of all the non-essential heavy metals, cadmium (cd) is perhaps the metal which has attracted most attention in soil science and plant nutrition due to its potential toxicity to 
man, and the relative mobility in the soil-plant system (McLaughlin and Singh, 1999). Cadmium is produced mainly as a by-product in mining and refining of $\mathrm{Zn}$, therefore its supply is more dependent on the $\mathrm{Zn}$ production than on the cd demand, cadmium is also recovered from recycled materials such as $\mathrm{Zn}-\mathrm{cd}$ batteries (Kabata-Pendias and Mukherjee, 2007). They are many studies that focused on the assessment of cadmium in soils, most of them are carried out in Iraq (Al-jumaily, 2016), Nigeria (Ololade, 2014), China (Ololade, 2014). The main aim of the present study to investigate the concentrations of cadmium which are considered potential carcinogens to humans.

\section{Materials and Methods Description of study area}

The study area, Kirkuk city for Dibbis area with geographical position being $\left(44^{\circ} 3^{\prime} 30.9^{\prime \prime}-44^{\circ} 5^{\prime} 40^{\prime \prime}\right.$ E) and $\left(35^{\circ} 39^{\prime} 10.8^{\prime \prime}-35^{\circ} 41^{\prime} 30^{\prime \prime} \mathrm{N}\right)$ is located in Northern Iraq (Fig.1). The area of Kirkuk Government equal around $(9676 \mathrm{~km} 2)$ from Iraq.

\section{Sampling Sites and Chemical analyses}

The soil samples were collected in July-2016 using an auger tool, it were collected at two depth between (0-10 $\mathrm{cm})$ and $(10-20 \mathrm{~cm})$, the samples represented by symbols, (S1-S8). The samples were dried on oven, pulverized and submitted to a screening process by 200 mesh sieves. The powder material of soil samples was stored in plastic sacks. The concentration of cadmium in soil was determined by employed assayed by the ICPMS techniques.

\section{Geological setting}

In order to facilitate the description of the exposed geological formations in the Kirkuk city, they are divided into four formation as well as recent deposit, each formation is described in a systematic style, starting with the type locality, age lithology and environmental deposition as follows:

\section{Fatha Formation (Middle Miocene)}

The type locality of the Fatha Formation is in Makhul Range, The lithology in the type section consists of green marl, limestone and gypsum as well as reddish brown claystone. It thickness in the type section is $445 \mathrm{~m}$ (Jassim et al., 1984). The depositional environment was a closed lagoon of hypersaline condition (Aqrawi et al., 2010).

\section{Injana Formation (Late Miocene)}

The type locality of the Injana Formation is along the northeastern limb of Himreen South anticline at Injana, The Injana Formation consists of Alternation of red, brown and grey clay stone, siltstone and sandstone as well as rare fresh water thin limestone and gypsum. It thickness in the type section is $620 \mathrm{~m}$. The Injana Formation has been interpreted as shallow water to subcontinental environment (Jassim et al., 1984).

\section{Mukdadiya Formation (Late Miocene - Pliocene)}

The type locality is along the northeastern limb of Himreen South anticline in Mukdadiya area with litology consists of Alternation of coarse sandstone; the sandstone is occasionally pebbly, clay stone and siltstone. It thickness in the type section is $2000 \mathrm{~m}$. The fluvial environment is a deposited environment of Mukdadiya Formation(Jassim et al., 1984).

\section{Bai Hassan Formation (Pliocene - Pleistocene)}

The type locality is in Bai Hassan anticline, northwest of Kirkuk city, it consists of Alternation of conglomerate, claystone and sandstone. The thickness of the Bai Hassan Formation is $638 \mathrm{~m}$ in the type section (Jassim et al., 1984). The Depositional Environment is a fluvio lacustrine environment (Buday, 1980).

\section{Quaternary Sediments}

The Quaternary sediments include different types of Pleistocene and Holocene sediments are Terraces (Pleistocene), Anthropogenic Sediments (PleistoceneHolocene), Alluvial Fan (Pleistocene - Holocene), Flood Plain (Holocene), Valley Fill Sediments (Holocene).

\section{Results and Discussion}

\section{Distribution of cadmium in Soil of Dibbis}

The present geochemistry study of cadmium show the concentration with average $(0.18 \mathrm{ppm})$ and range $(0.135$ $0.245 \mathrm{ppm}$ ) (table1 and figure2), the maximum concentration of cadmium is $(0.245 \mathrm{ppm})$ in Hai AlTaakhi (S1) because its station near the location of burial health the waste of city such as remember (Kiran Khanum et al., 2017), and Hai Al-Askari (S3) with average value (0.225),because this area was used in the past in agriculture are riched by phosphate fertilizer in addition to military district such as remember (Pinto et 
al., 2004), while (S8 and S5) represent HaiAl_Shuhadaa and Dur Al-kahrabashow values (0.21 and $0.195 \mathrm{ppm}$ ) respectively, that's men Dur Al-kahrabanear electric energy increasing cadmium in soil and Hai Al-Shuhadaa are from garden are riched by phosphate fertilizer(Hu et al., 2017).

\section{Indices of Pollution}

The soil contamination may be considered appreciable when concentrations of an element in soil and other environments were two-three times greater than the mean background levels (Logan and Miller, 1993). Evaluation for distribution of cadmium pollution is the most concerned (Hong-Gui et al., 2012). In recent study, geo accumulation index (Igeo), contamination factor (CF) and enrichment factor (EF) was applied to assess cadmium contamination in soil located within Dibis city.

\section{Geo-Accumulation Index (Igeo)}

The geo-accumulation index (Igeo) was used to assess cadmium pollution in soil of Dibbis city; it is showing by the following equation (Muller, 1969):

$$
\text { Igeo }=\log 2 \frac{\mathrm{Cm}}{1.5 * B m}
$$

Where $\mathrm{Cm}$ is the measured concentration of the examined metal $(\mathrm{Cd})$ in the soil and $\mathrm{Bm}$ is the geochemical background concentration of the metal $(\mathrm{Cd})$, the average of Cadmium earth's crust is $(\mathrm{Bn}=$ $0.1 \mathrm{ppm}$ ) (Turekian and Wedepohl, 1961), Factor 1.5 is the background correction of matrix factor due to lithogenic effects (Muller, 1969). Müller has using seven classes of geoaccumulation index, Class 0 (practically unpolluted), Igeo $\leq 0$; Class 1 (unpolluted to moderately polluted), $0<$ Igeo $<1$; Class 2 (moderately polluted), 1 $<$ Igeo $<2$; Class 3 (moderately to heavily polluted), 2 $<$ Igeo $<3$; Class 4 (heavily polluted), $3<$ Igeo $<4$; Class 5 (heavily to extremely polluted): $4<$ Igeo $<5$; Class 6 (extremely polluted), Igeo $>5$ (Muller, 1969).

The calculated Igeo values of $\mathrm{Cd}$ in all sites had been placed in (Table 2), which shows the degree of contamination of Dibissoil as (unpolluted to moderately polluted) for all sites.

\section{Contamination Factor $(\mathrm{CF})$}

The soil contamination was carried out using the contamination factorof toxic substance in a basin by (Hakanson, 1980). The Contamination factor (CF) is a ratio of the elements value $(\mathrm{Cd})$ in samples to preindustrial reference value for the element $(\mathrm{Cd})$. It is Showing by the following equation

$$
C F=\frac{\text { Cm sample }}{\text { Sb background }}
$$

Fig.1 Dibs map sowing sampling site

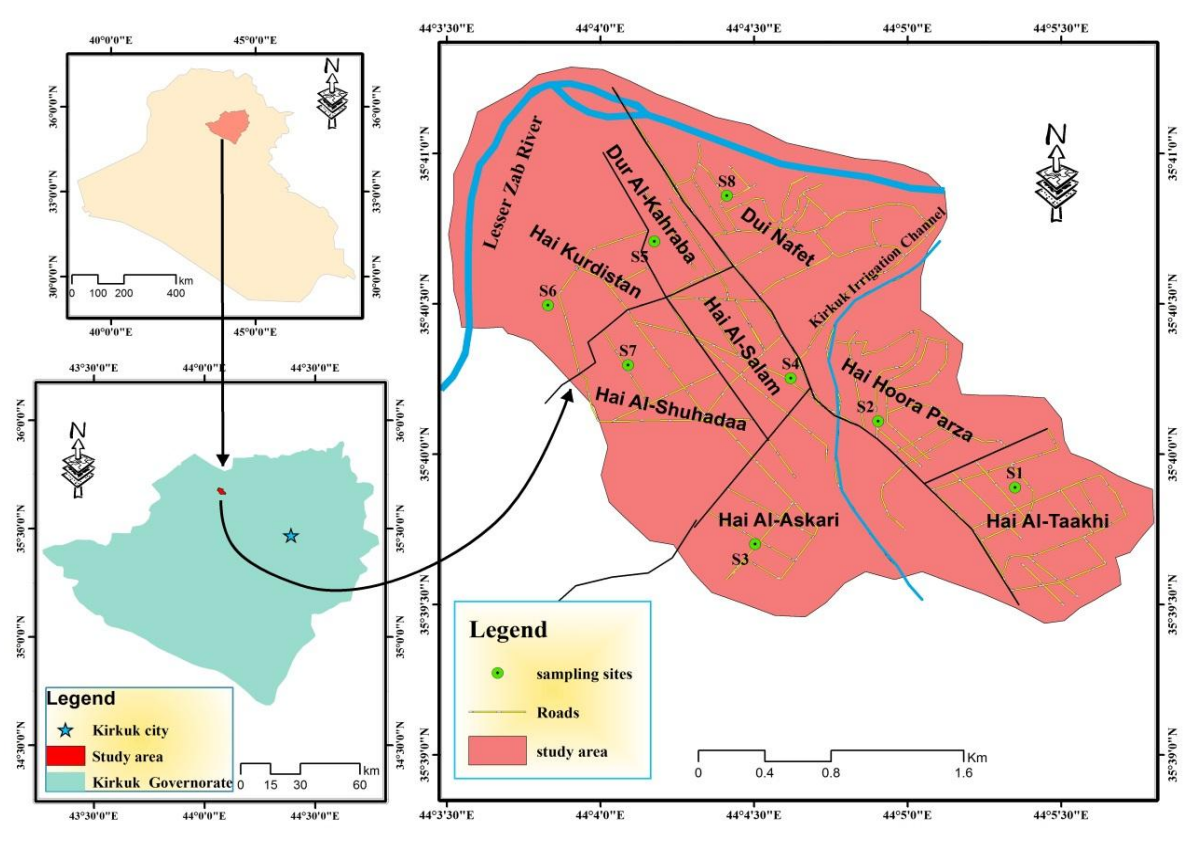


Fig.2 Concentration of cadmium in soil of Dibbis city with two depths

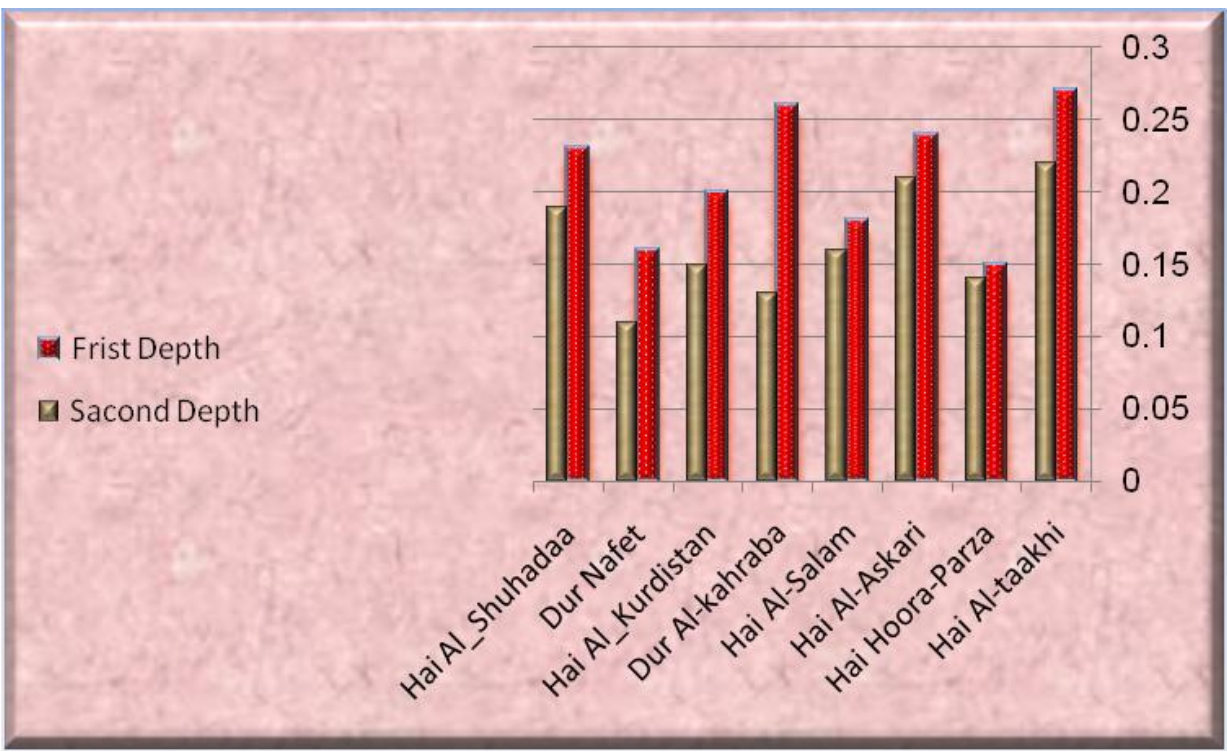

Table.1 Concentration of cadmium in soil of Dibbis city

\begin{tabular}{|c|c|c|c|c|}
\hline Quarter & Symbol & First depth & Second depth & Total \\
\hline Hai Al-taakhi & S1 & 0.27 & 0.22 & 0.245 \\
\hline HaiHoora-Parza & S2 & 0.15 & 0.14 & 0.145 \\
\hline Hai Al-Askari & S3 & 0.24 & 0.21 & 0.225 \\
\hline Hai Al-Salam & S4 & 0.18 & 0.16 & 0.17 \\
\hline Dur Al-kahraba & S5 & 0.26 & 0.13 & 0.195 \\
\hline HaiAl_Kurdistan & S6 & 0.2 & 0.15 & 0.175 \\
\hline DurNafet & S7 & 0.16 & 0.11 & 0.135 \\
\hline HaiAl_Shuhadaa & S 8 & 0.23 & 0.19 & 0.21 \\
\hline Min & & 0.15 & 0.11 & \\
\hline Mix & & 0.27 & 0.22 & \\
\hline Average & & 0.211 & 0.163 & \\
\hline
\end{tabular}

Table.2 The results of the Igeo, CF and EF in soil of Dibbis city-northern Iraq

\begin{tabular}{|c|c|c|c|c|c|}
\hline Name of Site & Cd ppm & Igeo & CF & V ppm background & EF \\
\hline \hline Hai Al-taakhi & 0.245 & 0.491 & 2.45 & 49 & 4.9 \\
\hline HaiHoora-Parza & 0.145 & 0.290 & 1.45 & 48 & 2.960 \\
\hline Hai Al-Askari & 0.225 & 0.451 & 2.25 & 49.5 & 4.454 \\
\hline Hai Al-Salam & 0.17 & 0.341 & 1.7 & 50 & 3.332 \\
\cline { 2 - 6 } Dur Al-kahraba & 0.195 & 0.391 & 1.95 & 47 & 4.065 \\
\cline { 2 - 6 } Hai Al-Kurdistan & 0.175 & 0.351 & 1.75 & 48 & 3.572 \\
\hline DurNafet & 0.145 & 0.270 & 1.45 & 49.5 & 2.870 \\
\hline Hai Al-Shuhadaa & 0.23 & 0.421 & 2.3 & 49 & 4.6 \\
\hline Average & 0.187 & 0.376 & 1.875 & 48.75 & 3.769 \\
\hline
\end{tabular}


Where the $\mathrm{Cm}$ sample is the values of metal $(\mathrm{Cd})$ in present study and $\mathrm{Cd}$ background is the average background of metal (cd) in earth's crust equal (0.1 ppm) (Turekian and Wedepohl, 1961). the contamination factor are characterized as follows: $(\mathrm{CF}<1$ indicates low contamination); ( $1<\mathrm{CF}<3$ is moderate contamination); ( $3<\mathrm{CF}<6$ is considerable contamination); and ( $\mathrm{CF}>6$ is very high contamination) (Hakanson, 1980).

The Contamination Factor of Cdinvestigated in soil of present study are presented in (Table 2), describe the class of contamination in soil of dibbissity is $(1 \leq \mathrm{CF}<3)$ (Moderate contamination) for all station.

\section{Enrichment Factor (EF)}

The enrichment factor is the relative abundance of a element in a soil compared to the background (Hernandez et al., 2003). The enrichment factor was calculated using the equation originally introduced by (Buat-Menard and Chesselet, 1979)as shown in the following shape:

\section{$\mathrm{EF}=\frac{(\mathrm{Cd} / \mathrm{V}) \text { sample }}{(\mathrm{Cd} / \mathrm{v}) \text { background }}$}

Where the $\mathrm{Cn}$ sample is the concentration of the examined element $(\mathrm{Cd})$ in the examined soil, Crefsample is the concentration of the examined element $(\mathrm{Cd})$ in the reference environment, for $\mathrm{Cd}$ is $(0.1 \mathrm{ppm})$ (Turekian and Wedepohl, 1961), Bnis the concentration of the reference element (Vanadium) in the examined environment (Schiff and Weisberg, 1999)(Table 2) and Bref is the concentration of the reference element(Vanaium) in the reference earth crust, for Vanaium is (98 ppm) (Turekian and Wedepohl, 1961). EF values were interpreted as follows: ( $\mathrm{EF}<1$ indicates no enrichment); (1-3 is minor enrichment); (3-5 is moderate enrichment); (5-10 is moderately severe enrichment); (10-25 is severe enrichment); (25-50 is very severe enrichment); and (>50 is extremely severe enrichment) (Sakan et al., 2009).

The Enrichment Factor results of the Cd investigated in this present study of soil are presented in (Table.2); the descriptive of enrichment is indicates Moderate enrichment with class $(2 \leq \mathrm{EF}<5)$.

\section{Conclusion}

This study has allowed the determination of the level of important cadmium at two layers of the soil. Based on the geo accumulation index (Igeo) the soils can be classified as " Unpolluted to moderately pollute ", contamination factors (CF) in soils (moderate contamination) and enrichment factors (EF) is indicated (moderate erichment) in all station.

\section{References}

Al-jumaily, H. A. A. (2016) “An Evaluation Performance of Potential Pollution of Arsenic, Chromium and Cadmium in the Road Side Soil of Kirkuk City, Northern Iraq," Geoscience and Environment Protection, 4, pp. 80-94. doi: 10.4236/gep.2016.49007.

Alina Kabata-Pendias (2011) Trace Elements in Soils and Plants. Boca Raton London New york: (CRC) Taylor \& Francis Group.

Aqrawi, A. A. M. et al., (2010) The petroleum geology of Iraq. Wiley Online Library.

ATSDR (2012) "Agency for Toxic Substance and Disease Registry, U.S. toxicological profile for cadmium. Department of Health and Humans Services,." Atlanta, Georgia, USA: Health Service, Centers for Disease Control.

Buat-Menard, P. and Chesselet, R. (1979) "Variable influence of the atmospheric flux on the trace metal chemistry of oceanic suspended matter," Earth and Planetary Science Letters. Elsevier, 42(3), pp. 399411.

Buday, T. (1980) The regional geology of Iraq: stratigraphy and paleogeography. State Organization.

Hakanson, L. (1980) "An ecological risk index for aquatic pollution control. A sedimentological approach," Water research. Elsevier, 14(8), pp. 975-1001.

Hernandez, L. et al.,(2003) "Heavy metal distribution in some French forest soils: Evidence for atmospheric contamination," Science of the Total Environment, 312(1-3), pp. 195-219. doi: 10.1016/S00489697(03)00223-7.

Hong-Gui, D. et al., (2012) "Comprehensive Assessment Model on Heavy Metal Pollution in Soil," Int. J. Electrochem. Sci, 7, pp. 5286-5296. Available at: www.electrochemsci.org.

Hu, B. et al., (2017) "Assessment of the potential health risks of heavy metals in soils in a coastal industrial region of the Yangtze River Delta," Environmental Science and Pollution Research. Environmental Science and Pollution Research, 24(24), pp. 1981619826. doi: 10.1007/s11356-017-9516-1.

Jassim, S. Z. et al., (1984) "Final report on the regional geological survey of Iraq," Stratigraphy. Baghdad: 
Geological Survey of Iraq.

Kabata-Pendias, A. and Mukherjee, A. B. (2007) Trace elements from soil to human. Springer Science \& Business Media.

Kabata-Pendias, A. and Szteke, B. (2015) Trace Elements in Abiotic and Biotic Environments. (CRC)Taylor \& Francis Group.

Kaji, M. (2012) "Role of experts and public participation in pollution control: The case of Itai-itai disease in Japan," Ethics in Science and Environmental Politics, 12(2), pp. 99-111. doi: 10.3354/esep00126.

Kiran Khanum et al., (2017) "Heavy metal toxicity and human health risk surveillances of wastewater irrigated vegetables in Lahore District, Pakistan," Carpathian Journal of Earth and Environmental Sciences, 12(2), pp. 403-412.

McLaughlin, M. J. and Singh, B. R. (1999) "Cadmium in soils and plants," in Cadmium in soils and plants. Springer, p. 282.

Muhammad Shahid, Camille Dumat, Sana Khalid, Nabeel Khan Niazi, A. P. M. C. A. (2016) "Cadmium Bioavailability, Uptake, Toxicity and Detoxification in Soil-Plant System," Reviews of Environmental Contamination and Toxicology, 240(June), p. 77. doi: 10.1007/398.

Muller, G. (1969) "Index of geoaccumulation in sediments of the Rhine River." GEO JOURNAL.

Ololade, I. A. (2014) "An Assessment of Heavy-Metal
Contamination in Soils within Auto-Mechanic Workshops Using Enrichment and Contamination Factors with Geoaccumulation Indexes," Journal of Environmental Protection, 5(August), pp. 970-982. doi: 10.4236/jep.2014.511098.

Pinto, A. P. et al.,(2004) "Influence of organic matter on the uptake of cadmium, zinc, copper and iron by sorghum plants," Science of the total environment. Elsevier, 326(1), pp. 239-247.

Rao, K. et al., (2011) "Review on cadmium removal from aqueous solutions," International Journal of Engineering, Science and Technology, 2(7), pp. 81103. doi: 10.4314/ijest.v2i7.63747.

Schiff, K.. and Weisberg, S.. (1999) "Iron as a reference element for determining trace metal enrichment in Southern California coastal shelf sediments," Marine Environmental Research, 48(2), pp. 161176. doi: 10.1016/S0141-1136(99)00033-1.

Terry J. Logan and Robert H.Miller (1993) "Background levels of heavy metals in Polish forest soils," Ecological Engineering, (February). Available at: http://www.sciencedirect.com/science/article/pii/092 5857494900531.

Turekian, K. K. and Wedepohl, K. H. (1961) "Distribution of the elements in some major units of the earth's crust," Geological Society of America Bulletin. Geological Society of America, 72(2), pp. 175-192.

\section{How to cite this article:}

Hassan A. A. Aljumaily and Ahmed H. M. Al-hamdany. 2017. Evaluation of Impact Cadmium on GeoEnvironment of Dibbis City in Kirkuk Government / Northern Iraq. Int.J.Curr.Res.Aca.Rev. 5(11), 19-24.

doi: https://doi.org/10.20546/ijcrar.2017.511.004 